\title{
Human metapneumovirus - what we know now [version 1;
}

\section{peer review: 2 approved]}

\author{
Nazly Shafagati, John Williams (iD \\ Department of Pediatrics, University of Pittsburgh School of Medicine, Pittsburgh, PA, USA
}

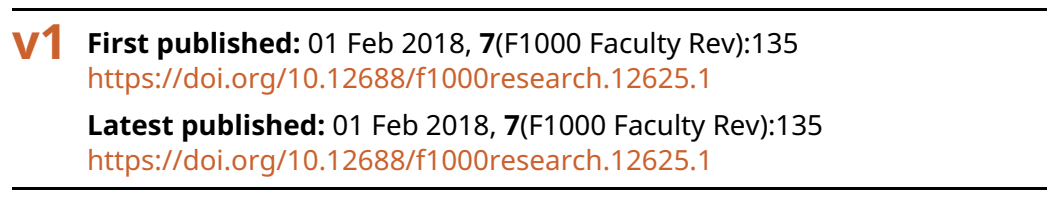

\section{Abstract}

Human metapneumovirus (HMPV) is a leading cause of acute respiratory infection, particularly in children, immunocompromised patients, and the elderly. HMPV, which is closely related to avian metapneumovirus subtype $C$, has circulated for at least 65 years, and nearly every child will be infected with HMPV by the age of 5 . However, immunity is incomplete, and re-infections occur throughout adult life. Symptoms are similar to those of other respiratory viral infections, ranging from mild (cough, rhinorrhea, and fever) to more severe (bronchiolitis and pneumonia). The preferred method for diagnosis is reverse transcription-polymerase chain reaction as HMPV is difficult to culture. Although there have been many advances made in the past 16 years since its discovery, there are still no US Food and Drug Administration-approved antivirals or vaccines available to treat HMPV. Both small animal and non-human primate models have been established for the study of HMPV. This review will focus on the epidemiology, transmission, and clinical manifestations in humans as well as the animal models of HMPV pathogenesis and host immune response.

\section{Keywords}

human metapneumovirus, acute respiratory infection, Viral pneumonia

\section{Open Peer Review}

Approval Status

1

2

\section{version 1}

$01 \mathrm{Feb} 2018$

Faculty Reviews are review articles written by the prestigious Members of Faculty Opinions. The articles are commissioned and peer reviewed before publication to ensure that the final, published version is comprehensive and accessible. The reviewers who approved the final version are listed with their names and affiliations.

1. Xiaoyong Bao, University of Texas Medical Branch, Galveston, USA

2. Jianrong Li, College of Veterinary Medicine, The Ohio State University, , Ohio, USA

Any comments on the article can be found at the end of the article. 
Corresponding author: John Williams (jvw@chp.edu)

Author roles: Shafagati N: Conceptualization, Writing - Original Draft Preparation, Writing - Review \& Editing; Williams J: Conceptualization, Funding Acquisition, Writing - Original Draft Preparation, Writing - Review \& Editing

Competing interests: JVW serves on a Scientific Advisory Board of Quidel and an Independent Data Monitoring Committee for GlaxoSmithKline. NS has no competing interests.

Grant information: JVW was supported by National Institutes of Health grant R01 AI-085062. NS was supported by National Institutes of Health grant T32 AI060525.

The funders had no role in study design, data collection and analysis, decision to publish, or preparation of the manuscript.

Copyright: $\odot 2018$ Shafagati $\mathrm{N}$ and Williams J. This is an open access article distributed under the terms of the Creative Commons Attribution License, which permits unrestricted use, distribution, and reproduction in any medium, provided the original work is properly cited.

How to cite this article: Shafagati $\mathrm{N}$ and Williams J. Human metapneumovirus - what we know now [version 1; peer review: 2 approved] F1000Research 2018, 7(F1000 Faculty Rev):135 https://doi.org/10.12688/f1000research.12625.1

First published: 01 Feb 2018, 7(F1000 Faculty Rev):135 https://doi.org/10.12688/f1000research.12625.1 


\section{Introduction}

The start of the twenty-first century has seen the discovery of several emerging or new respiratory pathogens causing human disease, including severe acute respiratory syndrome coronavirus and human metapneumovirus (HMPV). The metapneumoviruses are enveloped, non-segmented, negative-sense, single-stranded RNA viruses ${ }^{1}$. They comprise a genus of two species: avian metapneumovirus and HMPV. The metapneumoviruses belong to the order Mononegavirales and family Pneumoviridae, which also includes respiratory syncytial virus (RSV) ${ }^{2,3}$.

\section{Avian metapneumovirus}

Avian metapneumovirus (previously known as turkey rhinotracheitis virus) was discovered in 1978 in turkeys in South Africa ${ }^{4}$. Since then, the virus has been recognized to infect turkeys, chickens, and ducks worldwide with a significant economic impact $^{5}$. The virus has a low and variable mortality but high morbidity rate (up to 100\%) and causes severe upper respiratory infections as well reproductive issues leading to decreased egg production $^{5}$. There are currently four subtypes of avian metapneumovirus based on the genetic diversity of the attachment $(\mathrm{G})$ protein $^{6}$. Subtype A was first isolated in South Africa, followed by subtype B in several European countries. Subtype C was discovered in the US in $1996^{7}$, and subtype D was identified in France in $2000^{8}$. It is thought that wild migratory birds play a key role in the spread of avian metapneumovirus ${ }^{5}$.

\section{Discovery of human metapneumovirus}

In 2001, researchers in the Netherlands first identified HMPV from stored nasopharyngeal samples from 28 children with respiratory illness by using electron microscopy and random reverse transcription-polymerase chain reaction (RT-PCR) techniques. This novel virus exhibited cytopathic effect but not hemadsorption in tertiary monkey kidney epithelial cells. The genome was most closely related to avian metapneumovirus serotype C (up to $88 \%$ homology). However the newly discovered virus replicated efficiently in monkeys but not in birds $^{2}$. Archived sera from the 1950s contained neutralizing antibodies against $\mathrm{HMPV}^{2}$. Two retrospective Canadian studies detected HMPV in specimens collected from patients with respiratory illness between 1993 and 2001,10, and a US study detected HMPV in specimens from 1976 to $2001^{11}$. Collectively, these studies show that HMPV has been circulating undetected for many decades.

\section{Genome organization and structure}

HMPV is a negative-sense, non-segmented, single-stranded RNA virus. The genome is about 13,000 nucleotides in length and is composed of eight genes encoding for nine proteins: nucleoprotein $(\mathrm{N})$, phosphoprotein $(\mathrm{P})$, matrix protein $(\mathrm{M})$, fusion protein $(\mathrm{F})$, matrix-2 proteins (M2-1 and M2-2), small hydrophobic $(\mathrm{SH})$ protein, glycoprotein $(\mathrm{G})$, and large (L) polymerase protein (Table 1$)^{12-21}$. As in other paramyxoviruses, the N, L, and $\mathrm{P}$ proteins form the viral replication complex. Though similar in genome to RSV, both avian metapneumovirus and HMPV possess a gene order different from that of RSV and lack the non-structural proteins NS1 and NS2 ${ }^{1}$. HMPV exhibits a paramyxovirus-like morphology, ranging from 150 to $600 \mathrm{~nm}$ in size, enveloped with short protein spike projections ${ }^{2}$.

Several respiratory viruses form filamentous viral particles in vitro. A recent study demonstrated that HMPV infection led to the formation of branched viral filamentous networks and intercellular extensions in human bronchial epithelial cells ${ }^{22}$. HMPV P protein co-localized with actin and induced the formation of the intercellular extensions. Importantly, HMPV spread directly from cell to cell even in the presence of neutralizing antibodies and in the absence of the attachment factor heparan sulfate. This direct viral spread was mediated by the actin cytoskeleton, CDc42, and Rac122.

Table 1. Summary of human metapneumovirus proteins and function.

\begin{tabular}{|l|l|l|l|}
\hline Gene & Protein & $\begin{array}{l}\text { Amino } \\
\text { acid length }\end{array}$ & Function \\
\hline N & Nucleoprotein & 394 & RNA genome encapsidation \\
\hline P & Phosphoprotein & 294 & Polymerase co-factor \\
\hline M & Matrix protein & 254 & Aids in viral assembly and budding \\
\hline F & Fusion protein & 539 & Virus-cell binding and membrane fusion \\
\hline M2 & M2-1 protein & 187 & RNS transcription processivity factor \\
\hline & M2-2 protein & 71 & Regulates RNA transcription/replication \\
\hline SH & Small hydrophobic protein & $177-183$ & Possible viroporin or innate immune inhibition \\
\hline G & Attachment glycoprotein & $229-236$ & Binds to cellular glycosaminoglycans \\
\hline L & Large polymerase protein & 2,005 & Catalytic activity for viral replication \\
\hline
\end{tabular}




\section{Viral replication}

Replication of HMPV occurs in the nasal and lung tissues, and airway epithelial cells are the primary target of HMPV. HMPV is thought to attach to the target cell via $G$ protein interactions with heparan sulfate and other glycosaminoglycans ${ }^{21,23}$. The HMPV $F$ protein encodes an RGD (Arg-Gly-Asp) motif that engages RGD-binding integrins as cellular receptors ${ }^{16,24,25}$ and then mediates fusion of the cell membrane and viral envelope in a $\mathrm{pH}$-independent fashion, likely within endosomes ${ }^{5,26-28}$. Low $\mathrm{pH}-$ dependent fusion is a rare occurrence in only certain lineage A F proteins $^{29}$. As with other negative-sense, single-stranded RNA viruses, HMPV negative-sense genomic RNA is transcribed to positive-sense mRNA by the RNA polymerase before translation. After translation, the viral glycoproteins are transported from the endoplasmic reticulum through the Golgi apparatus to the plasma membrane. As nascent viral proteins accumulate, the polymerase switches from transcribing monocistronic mRNA to replicating full-length positive-sense antigenome to serve as a template for progeny negative-sense genomes. Newly synthesized virions exit the host via budding from the plasma membrane, which is facilitated by the M protein $^{30,31}$.

\section{Phylogenetic groups}

There are two major genetic lineages, $\mathrm{A}$ and $\mathrm{B}$, further divided into the sublineages (or clades) A1, A2, B1, and B2 ${ }^{32-35}$. All HMPV genes fall into these four clades, suggesting that genome recombination is very rare $^{33}$. Although both genotypes A and B can co-circulate, the dominant lineage may vary year by year ${ }^{33,36}$. Phylogenetic analyses of HMPV suggest that the human virus diverged from the avian type C 200-400 years ago ${ }^{33-35,37}$. HMPV cannot productively infect birds; thus, if HMPV did arise in humans as a zoonotic infection, the virus is now adapted fully to humans ${ }^{2}$. Evidence suggests that the different genetic lineages of metapneumovirus do not represent distinct serotypes; studies in rodents and non-human primates show a high degree of cross-neutralization and cross-protection between subgroups ${ }^{38-41}$.

\section{Epidemiology}

HMPV has a seasonal distribution that is similar to that of other respiratory viruses and tends to peak in later months compared with RSV and influenza ${ }^{11,41-45}$. Similar to other respiratory pathogens, HMPV causes most severe disease in infants and young children, the elderly, and persons with underlying chronic conditions such as asthma, emphysema, and immune compromise. Seroepidemiology studies have shown that most children worldwide are infected with HMPV by the age of $5^{2,46-50}$.

\section{Children}

Rates of hospitalization of children for HMPV infection are highest in the first year of life but occur throughout early childhood. Many studies report that the peak age of hospitalization for HMPV is between 6 and 12 months of age, which is later than the peak age of hospitalization for RSV (2-3 months) ${ }^{44,51-56}$. Through the course of a year, multiple subgroups of HMPV will often be in circulation. These subgroups are genetically distinct and can vary across seasons, with one lineage being more prevalent in a given season ${ }^{45,57}$. Despite genetic differences between the subgroups, all remain capable of causing severe infection, and the differences have not been associated consistently with the variation in severity of disease ${ }^{58,59}$. HMPV infection usually causes overt disease; the virus is rarely detected in asymptomatic children $^{11,44,60-63}$. Studies of hospitalized and outpatient children worldwide have found HMPV to be associated with 6 to $40 \%$ of acute respiratory illness ${ }^{11,41,44-46,51-53,64-67}$.

\section{Adults}

Although nearly all populations will experience primary HMPV infection by age 5, HMPV re-infection occurs throughout adult life. HMPV was identified in up to $13 \%$ of hospitalized adults in Rochester, New York $^{43}$. Whereas HMPV infection is typically mild in otherwise healthy younger adults, infection with HMPV leads to increased disease severity and high morbidity and mortality rates in the elderly. A retrospective Canadian study showed that $46 \%$ of $\mathrm{HMPV}^{+}$cases were from patients at least 65 years, and $60 \%$ of these elderly patients were hospitalized ${ }^{10}$. A subsequent study reported that at least $50 \%$ of the $\mathrm{HMPV}^{+}$elderly patients infected during an outbreak in a long-term care facility developed bronchitis or pneumonia, leading to $50 \%$ mortality ${ }^{68}$.

\section{Underlying conditions}

Pre-existing conditions, particularly asthma, play a role in disease severity and hospitalization. HMPV was isolated from $7 \%$ of adults hospitalized for an acute asthma exacerbation ${ }^{69}$. Like infection with RSV, infection with HMPV within the first two years of life is a risk factor for later asthma ${ }^{70}$. One study found that $16 \%$ of $\mathrm{HMPV}^{+}$patients had asthma compared with none of the $\mathrm{RSV}^{+}$patients ${ }^{54}$. Another study noted a previous asthma diagnosis in $41 \%$ of $\mathrm{HMPV}^{+}$children between the ages of 5 and $13^{42}$.

Immunocompromised patients and those with underlying medical conditions can be severely affected by HMPV. One study found that many $\mathrm{HMPV}^{+}$hospitalized patients over the age of 5 had other severe diseases, such as cystic fibrosis or lymphoma ${ }^{54}$. Another retrospective study found that of 39 immunocompromised children with HMPV, 17 developed pneumonia and four died from respiratory failure ${ }^{71}$. In a group of patients between the age of 15 and 65 years, $67 \%$ had underlying medical conditions, such as lymphoma or lung tumors ${ }^{10}$.

Co-infections with other viral or bacterial pathogens may exacerbate symptoms and disease. Viral co-infection rates in patients with HMPV range from 6 to $23 \%{ }^{11,42,43}$, but viral co-infections do not seem to impact disease severity ${ }^{11}$. However, secondary bacterial pneumonia can occur and is associated with increased mortality ${ }^{72-74}$.

\section{Transmission and symptoms}

HMPV is thought to spread through direct or close contact with infected individuals or objects (fomites) ${ }^{36}$. Symptoms and disease presentation of HMPV are similar to those of other respiratory viruses causing both upper and lower respiratory tract infections. Symptoms can include cough, rhinorrhea, sore throat, and fever as well as lower respiratory tract symptoms such as wheezing, difficulty breathing, and hypoxia ${ }^{54,75}$. The clinical diagnoses most commonly associated with HMPV are bronchiolitis and pneumonia ${ }^{42}$. 


\section{Animal models}

Although early studies demonstrated that HMPV does not replicate or cause disease in birds ${ }^{2}$, small animal models such as mice, cotton rats, and hamsters as well as non-human primates are semi-permissive ${ }^{40}$. Several studies show that cotton rats are the most permissive small animal model and that peak virus titers occurred at day four post infection ${ }^{76-78}$. Viral lung replication and disease vary between different inbred mouse strains; most work has been published in the BALB/c model, which exhibits substantial disease symptoms ${ }^{79-88}$. BALB/c and C57BL/6 mice may exhibit clinical symptoms such as difficulty breathing, weight loss, and ruffled fur, partly depending on the virus strain and inoculum ${ }^{80,83,89}$. Histological scoring revealed that lung pathology is most severe between days 5 and 7 but is significantly decreased by day 14. Viral replication occurs for up to 10-14 days in mice, and peak viral load is at day $5^{80,83,89}$. Similar to older humans, aged mice have increased disease severity, higher viral titers, and diminished immune response compared with younger mice $^{90}$. However, unlike humans, in whom re-infection occurs throughout life, immunocompetent mice cannot be productively re-infected with HMPV. Of note, most work has been published in the BALB/c inbred strain, based on the extensive body of RSV research, but some investigators have focused on the C57BL/6 model.

In contrast, cotton rats, hamsters, and ferrets infected with HMPV do not manifest observable clinical symptoms ${ }^{2,40,83,91}$. In hamsters and ferrets, there is high viral replication in the respiratory tract compared with mice ${ }^{40}$. Both African green monkeys and rhesus macaques are permissive for HMPV infection, but neither exhibits clinical symptoms. HMPV replication and neutralizing antibody production are higher in African green monkeys compared with rhesus macaques ${ }^{40,92}$.

\section{Pathogenesis and immunity}

Humans and animals mount neutralizing antibody responses to HMPV. In mice, neutralizing antibodies are first detected five to seven days after infection, peaking between four and six weeks after infection. In mouse models, initial infection with HMPV protects against re-infection ${ }^{40,80}$, and antibodies alone can protect in small animal models ${ }^{93-96}$. In contrast, when macaques were challenged 12 weeks after primary HMPV infection, virus replication was detectable despite the presence of serum antibodies, and when challenged 8 months after primary infection, there was no protection ${ }^{97}$. These data suggest that in primates and humans, antibody levels wane over time, facilitating re-infection. A prospective study in humans noted that baseline HMPV antibodies were lower in older adults who subsequently became infected versus those who did not become infected ${ }^{98}$, suggesting a protective effect of antibodies.

Cytotoxic T lymphocytes (CTLs) contribute to clearance of HMPV infection in mice ${ }^{80,89,99-101}$. As early as day 1 post infection, there is an infiltration of lymphocytes, monocytes, and other mononuclear cells to perivascular and peribronchial areas of the lung. There is an increase in the number of total bronchoalveoloar lavage cells that starts at day 1 , peaks at day 7 , and returns to near normal numbers by day $21^{80}$. The number of neutrophils and mononuclear cells increases by day 3 until day 14 post infection.
$\mathrm{CD}^{+} \mathrm{T}$ cells peak earlier at day 6 whereas $\mathrm{CD} 8^{+} \mathrm{T}$ cells peak between day 8 and $10^{80,89,100}$. Furthermore, the depletion of $\mathrm{T}$ cells leads to prolonged viral replication ${ }^{80,99,101}$, and T-cell epitope vaccination alone can reduce viral titers ${ }^{89,100}$. The role of natural killer (NK) cells is unclear. One study depleted NK cells with anti-CD49 antibody and reported prolonged viral replication ${ }^{99}$, whereas another depleted NK cells with the more specific antibody anti-NK1.1 and found no effect ${ }^{88}$.

Although $\mathrm{T}$ cells play a critical role in disease protection, they also contribute to disease severity caused by HMPV. The depletion of either $\mathrm{CD}^{+}$or $\mathrm{CD}^{+} \mathrm{T}$ cells led to significantly less weight loss, decreased lung inflammation, and reduced airway obstruction ${ }^{80}$. These results collectively show that $\mathrm{T}$ cells, especially $\mathrm{CD}^{+} \mathrm{T}$ cells, play a role in enhancing clinical disease and lung pathology.

HMPV, like other respiratory viruses, dampens the immune response after infection, but the specific mechanisms remain unclear. Multiple studies demonstrate convincingly that HMPV can interfere with the type I interferon (IFN) response, but different studies have implicated various viral proteins, including G, M2-2, $\mathrm{P}$, or $\mathrm{SH}$, and suggested diverse mechanisms ${ }^{19,102-105}$. Type I IFN receptor (IFNAR)-deficient mice infected with HMPV had higher lung viral titers than wild-type (WT) mice but less lung inflammation and airway dysfunction, highlighting the importance of the IFN pathway for HMPV clearance and disease ${ }^{86}$. HMPV is capable of infecting human and murine dendritic cells in vitro, leading to altered signaling, diminished cytokine production, decreased migration, and reduced capacity to activate $\mathrm{CD} 4^{+} \mathrm{T}$ cells ${ }^{106-112}$. However, the contribution of these interactions to disease and protection in vivo has not been defined.

One way that HMPV evades the adaptive immune response is through the upregulation of programmed cell death-1 (PD-1), a T-cell surface receptor that plays a critical role in downregulating the immune response, leading to $\mathrm{CD}^{+} \mathrm{T}$-cell functional impairment. This phenomenon is similar to $\mathrm{CD}^{+} \mathrm{T}$-cell exhaustion described in chronic infections and cancer ${ }^{113}$. During infection with HPMV and other acute respiratory viruses, there is an upregulation of both PD-1 and its ligand, PD-L1, in the lungs but not splenic $\mathrm{CD}^{+} \mathrm{T}$ cells. Blocking PD-1 ligation prevented functional impairment of $\mathrm{HMPV}$-specific $\mathrm{CD}^{+} \mathrm{T}$ cells in the lung, and mice lacking PD-1 had a greater percentage of functional HMPV-specific CD8 ${ }^{+} \mathrm{T}$ cells compared with WT mice ${ }^{89}$. During secondary HMPV infection, lung $\mathrm{CD}^{+}$T-cell effector functions were severely impaired after re-infection and PD-1 expression was high; blockade of PD-1 ligation enhanced CD8 ${ }^{+}$ T-cell function ${ }^{100}$. These results collectively suggest that the PD-1/PD-L1 pathway plays an important role in evading the immune response during primary and secondary HMPV infections and may contribute to re-infection.

\section{Diagnosis}

The standard method for HMPV diagnosis has been nucleic acid amplification tests, such as RT-PCR ${ }^{114-116}$. Several commercial multiplex molecular assays that include HMPV are available ${ }^{117}$. Viral culture and serological testing are insensitive ${ }^{2}$. One reason for the delayed discovery of HMPV is the difficulty of growing 
the virus in cell culture. The virus requires exogenous trypsin to replicate in vitro and while capable of growth in other cell lines, it produces robust cytopathic effects in tertiary monkey kidney and LLC-MK2 (rhesus kidney) cells ${ }^{2,118}$. Furthermore, viral propagation can take 14 days or longer.

\section{Antiviral treatments}

Treatment consists of supportive care as there are no licensed antivirals against HMPV. Two potential treatments that have been investigated are ribavirin and immunoglobulin. Ribavarin is a nucleoside with activity against RNA viruses and exhibits in vitro activity against $\mathrm{HMPV}^{119}$ and exhibited some efficacy in mice $^{120}$. Commercial intravenous immunoglobulin (IVIG) contains neutralizing activity against $\mathrm{HMPV}^{119}$, and as noted above, antibodies alone exhibit efficacy both prophylactically and therapeutically in mice ${ }^{93-96}$. There are anecdotal reports of human use of ribavirin and $\mathrm{IVIG}^{121}$ but no controlled trials and no guidelines to recommend the use of these measures.

\section{Vaccine development}

There are currently no licensed vaccines for HMPV, but numerous efforts have been made to develop a safe and effective vaccine. Early cross-challenge studies with hamsters showed that infection with subgroup A produced an immune response that protected from a subsequent challenge with subgroup B and vice versa $^{40}$.

There have been several promising live-attenuated vaccines. A cold-adapted, live-attenuated HMPV vaccine provided complete protection in hamsters ${ }^{122}$. While antibody levels were increased after immunization in cynomolgus macaques, immunization did not provide complete protection from viral replication after challenge $^{123}$. Recombinant HMPV (rHMPV) viruses lacking the G, M2-1, M2-2, or SH protein have exhibited an attenuated and immunogenic phenotype in animal models ${ }^{15,124,125}$. Mutations in the methyl transferase domains of the polymerase or the integrinbinding RGD motif of the F protein were attenuated, immunogenic, and protective in cotton rats ${ }^{126,127}$.

Vectored vaccine approaches that have been effective in animal models include chimeric rHMPV containing the avian metapneumovirus $\mathrm{P}$ protein $^{128}$, alphavirus-vectored HMPV $\mathrm{F}^{129,130}$, bovine PIV3 vectored $\mathrm{F}^{39}$, or Sendai virus vectored $\mathrm{F}^{131}$. The establishment of a human challenge model $^{132}$ and a successful test of a live-attenuated candidate in seropositive adults ${ }^{133}$ provides a platform for future clinical trials.

Another method of vaccination is with heat-killed or formalininactivated virus, but a major concern for non-replicating HMPV vaccines is the experience in the 1960s with formalininactivated RSV (FI-RSV) vaccines ${ }^{134-136}$. FI-RSV induced an aberrant immune response that failed to protect and led to enhanced respiratory disease in vaccinees upon natural RSV infection. Animal studies replicated the results of the FI-RSV clinical trials $^{137,138}$. Similar to FI-RSV, FI-HMPV and heat-inactivated HMPV vaccines in mice, cotton rats, and macaques led to enhanced disease following viral infection and to high mortality and increased levels of cytokines and lung inflammation ${ }^{139-141}$.
These studies show that these kinds of vaccines not only do not induce protective immunity but may lead to increased morbidity and mortality.

In comparison with inactivated vaccines, subunit vaccines that contain partial or full-length viral proteins, particularly the HMPV F protein, have been more encouraging. Several studies of recombinant $\mathrm{F}$ protein report protective immunity without enhanced disease in cotton rats, hamsters, and non-human primates $^{91,123}$. Another non-replicating vaccine approach is viruslike particles using HMPV $\mathrm{M}$ and $\mathrm{F}$ proteins expressed in human embryonic kidney epithelial cells ${ }^{101,123,142}$ or generated using retroviral vectors ${ }^{143}$. All of these approaches have induced neutralizing antibodies and in some cases functional T-cell responses $^{101,142}$, leading to protection without signs of enhanced disease. Unfortunately, although subunit vaccines do induce immune responses when challenged with HMPV, the immune response may rapidly wane over time and may require multiple immunizations.

CTL epitopes have been employed as peptide vaccines in mice. CTL epitope vaccines protected mice from HMPV infection by reducing viral load and lung immunopathology, generating effector and memory $\mathrm{T}$-cell response, enhancing $\mathrm{T}$ helper 1 (Th1)-type cytokine expression, and reducing Th2-type cytokine expression ${ }^{144}$. Other peptide vaccine approaches have induced functional memory $\mathrm{CD}^{+} \mathrm{T}$ cells that were associated with reduced viral titers ${ }^{89,100,142}$. A recent study constructed a multiepitope peptide (MEP), consisting of six B-cell epitopes, four CTL epitopes, and two T helper cell epitopes. MEP caused both strong humoral immunity, as indicated by increased antibody levels, and cell-mediated immunity, as indicated by increased lymphocyte levels and activity ${ }^{145}$.

\section{Future directions}

Although HMPV was only discovered in 2001, there have been many advances in understanding mechanisms by which HMPV causes disease. Serologic and evolutionary studies indicate that HMPV has circulated for many years undetected. Robust animal models have been established, and candidate vaccines and antibodies have been developed. However, there is still much in the field regarding pathogenesis, immunity, antivirals, and vaccines that is yet to be discovered.

\section{Competing interests}

JVW serves on a Scientific Advisory Board of Quidel and an Independent Data Monitoring Committee for GlaxoSmithKline. NS has no competing interests.

\section{Grant information}

JVW was supported by National Institutes of Health grant R01 AI085062. NS was supported by National Institutes of Health grant T32 AI060525.

The funders had no role in study design, data collection and analysis, decision to publish, or preparation of the manuscript. 
1. Hamelin ME, Abed Y, Boivin G: Human metapneumovirus: a new player among respiratory viruses. Clin Infect Dis. 2004; 38(7): 983-90.

PubMed Abstract | Publisher Full Text

2. van den Hoogen BG, de Jong JC, Groen J, et al:: A newly discovered human pneumovirus isolated from young children with respiratory tract disease. Nat Med. 2001; 7(6): 719-24.

PubMed Abstract | Publisher Full Text

3. F Afonso CL, Amarasinghe GK, Bányai K et al: Taxonomy of the order Mononegavirales: update 2016. Arch Virol. 2016; 161(8): 2351-60. PubMed Abstract | Publisher Full Text | Free Full Text | F1000 Recommendation

4. McDougall JS, Cook JK: Turkey rhinotracheitis: preliminary investigations. Vet Rec. 1986; 118(8): 206-7.

PubMed Abstract | Publisher Full Text

5. Easton AJ, Domachowske JB, Rosenberg HF: Animal pneumoviruses: molecular genetics and pathogenesis. Clin Microbiol Rev. 2004; 17(2): 390-412. PubMed Abstract | Publisher Full Text | Free Full Text

6. Juhasz K, Easton AJ: Extensive sequence variation in the attachment (G) protein gene of avian pneumovirus: evidence for two distinct subgroups. J Gen Virol. 1994; 75(Pt 11): 2873-80.

PubMed Abstract | Publisher Full Text

7. Seal BS: Matrix protein gene nucleotide and predicted amino acid sequence demonstrate that the first US avian pneumovirus isolate is distinct from European strains. Virus Res. 1998; 58(1-2): 45-52. PubMed Abstract | Publisher Full Text

8. Bäyon-Auboyer MH, Arnauld C, Toquin D, et al:: Nucleotide sequences of the F, L and $G$ protein genes of two non-A/non-B avian pneumoviruses (APV) reveal a novel APV subgroup. J Gen Virol. 2000; 81(Pt 11): 2723-33. PubMed Abstract | Publisher Full Text

9. Peret TC, Boivin G, Li Y, et al:: Characterization of human metapneumoviruse isolated from patients in North America. $J$ Infect Dis. 2002; 185(11): 1660-3. PubMed Abstract | Publisher Full Text

10. Boivin $G$, Abed $Y$, Pelletier $G$, et al.: Virological features and clinical manifestations associated with human metapneumovirus: a new paramyxovirus responsible for acute respiratory-tract infections in all age groups. J Infect Dis. 2002; 186(9): 1330-4. PubMed Abstract | Publisher Full Text

11. Williams JV, Harris PA, Tollefson SJ, et al.: Human metapneumovirus and lower respiratory tract disease in otherwise healthy infants and children. $N$ Engl $J$ Med. 2004; 350(5): 443-50.

PubMed Abstract | Publisher Full Text | Free Full Text

12. van den Hoogen BG, Bestebroer TM, Osterhaus AD, et al.: Analysis of the genomic sequence of a human metapneumovirus. Virology. 2002; 295(1): 119-32. PubMed Abstract | Publisher Full Text

13. Biacchesi S, Skiadopoulos MH, Boivin G, et al.: Genetic diversity between human metapneumovirus subgroups. Virology. 2003; 315(1): 1-9. PubMed Abstract | Publisher Full Text

14. Piyaratna R, Tollefson SJ, Williams JV: Genomic analysis of four human metapneumovirus prototypes. Virus Res. 2011; 160(1-2): 200-5. PubMed Abstract | Publisher Full Text | Free Full Text

15. Biacchesi S, Skiadopoulos MH, Yang L, et al:: Recombinant human Metapneumovirus lacking the small hydrophobic $\mathrm{SH}$ and/or attachment $\mathrm{G}$ glycoprotein: deletion of $\mathrm{G}$ yields a promising vaccine candidate. J Virol. 2004 78(23): 12877-87.

PubMed Abstract | Publisher Full Text | Free Full Text

16. F Chang A, Masante C, Buchholz UJ, et al:: Human metapneumovirus (HMPV) binding and infection are mediated by interactions between the HMPV fusion protein and heparan sulfate. J Virol. 2012; 86(6): 3230-43. PubMed Abstract | Publisher Full Text | Free Full Text | F1000 Recommendation

17. Derdowski A, Peters TR, Glover N, et al:: Human metapneumovirus nucleoprotein and phosphoprotein interact and provide the minimal requirements for inclusion body formation. J Gen Virol. 2008; 89(Pt 11): 2698-708. PubMed Abstract | Publisher Full Text | Free Full Text

18. Fearns R, Collins PL: Role of the M2-1 transcription antitermination protein of respiratory syncytial virus in sequential transcription. $J$ Virol. 1999; 73(7): 5852-64.

PubMed Abstract | Free Full Text

19. Ren J, Wang $\mathrm{Q}$, Kolli $\mathrm{D}$, et al:: Human metapneumovirus M2-2 protein inhibits innate cellular signaling by targeting MAVS. J Virol. 2012; 86(23): 13049-61. PubMed Abstract | Publisher Full Text | Free Full Text

20. Masante C, EI Najjar F, Chang A, et al:: The human metapneumovirus small hydrophobic protein has properties consistent with those of a viroporin and can modulate viral fusogenic activity. J Virol. 2014; 88(11): 6423-33. PubMed Abstract | Publisher Full Text | Free Full Text

21. Thammawat S, Sadlon TA, Hallsworth PG, et al:: Role of cellular glycosaminoglycans and charged regions of viral $\mathrm{G}$ protein in human metapneumovirus infection. J Virol. 2008; 82(23): 11767-74. PubMed Abstract | Publisher Full Text | Free Full Text
22. $\mathrm{F}$ EI Najjar F, Cifuentes-Muñoz N, Chen J, et al.: Human metapneumovirus nduces Reorganization of the Actin Cytoskeleton for Direct Cell-to-Cell Spread. PLoS Pathog. 2016; 12(9): e1005922.

PubMed Abstract | Publisher Full Text | Free Full Text | F1000 Recommendation

23. Adamson $\mathrm{P}$, Thammawat $\mathrm{S}$, Muchondo $\mathrm{G}$, et al:: Diversity in glycosaminoglycan binding amongst hMPV G protein lineages. Viruses. 2012; 4(12): 3785-803. PubMed Abstract | Publisher Full Text | Free Full Text

24. Cseke G, Maginnis MS, Cox RG, et al: Integrin alphavbeta1 promotes infection by human metapneumovirus. Proc Natl Acad Sci U S A. 2009; 106(5): 1566-71. PubMed Abstract | Publisher Full Text | Free Full Text

25. Cox RG, Livesay SB, Johnson M, et al:: The human metapneumovirus fusion protein mediates entry via an interaction with RGD-binding integrins. $J$ Virol. 2012; 86(22): 12148-60.

PubMed Abstract | Publisher Full Text | Free Full Text

26. Cox RG, Mainou BA, Johnson M, et al.: Human Metapneumovirus Is Capable of Entering Cells by Fusion with Endosomal Membranes. PLoS Pathog. 2015; 11(12): e1005303.

PubMed Abstract | Publisher Full Text | Free Full Text

27. Yang $\mathrm{H}, \mathrm{He} \mathrm{H}$, Tan $\mathrm{B}$, et al.: Human metapneumovirus uses endocytosis pathway for host cell entry. Mol Cell Probes. 2016; 30(4): 231-7. PubMed Abstract | Publisher Full Text

28. Schowalter RM, Smith SE, Dutch RE: Characterization of human metapneumovirus F protein-promoted membrane fusion: critical roles for proteolytic processing and low pH. J Virol. 2006; 80(22): 10931-41.

PubMed Abstract | Publisher Full Text | Free Full Text

29. Herfst S, Mas V, Ver LS, et al:: Low-pH-induced membrane fusion mediated by human metapneumovirus $F$ protein is a rare, strain-dependent phenomenon. J Virol. 2008; 82(17): 8891-5.

PubMed Abstract | Publisher Full Text | Free Full Text

30. Lamb RA, Kolakofsky D: Paramyxoviridae: The viruses and their replication. 1996. Reference Source

31. F Leyrat C, Renner M, Harlos K, et al.: Structure and self-assembly of the calcium binding matrix protein of human metapneumovirus. Structure. 2014; 22(1): $136-48$

PubMed Abstract | Publisher Full Text | Free Full Text | F1000 Recommendation

32. van den Hoogen BG, Herfst S, Sprong $L$, et al:: Antigenic and genetic variability of human metapneumoviruses. Emerg Infect Dis. 2004; 10(4): 658-66. PubMed Abstract | Publisher Full Text | Free Full Text

33. F Kim Jl, Park S, Lee I, et al:: Genome-Wide Analysis of Human Metapneumovirus Evolution. PLoS One. 2016; 11(4): e0152962.

PubMed Abstract | Publisher Full Text | Free Full Text | F1000 Recommendation

34. de Graaf M, Osterhaus AD, Fouchier RA, et al.: Evolutionary dynamics of human and avian metapneumoviruses. J Gen Virol. 2008; 89(Pt 12): 2933-42. PubMed Abstract | Publisher Full Text

35. Yang CF, Wang CK, Tollefson SJ, et al: Human metapneumovirus G protein is highly conserved within but not between genetic lineages. Arch Virol. 2013; 158(6): 1245-52.

PubMled Abstract | Publisher Full Text | Free Full Text

36. Haas LE, Thijsen SF, van Elden L, et al:: Human metapneumovirus in adults. Viruses. 2013; 5(1): 87-110.

PubMed Abstract | Publisher Full Text | Free Full Text

37. Yang CF, Wang CK, Tollefson SJ, et al: Genetic diversity and evolution of human metapneumovirus fusion protein over twenty years. Virol J. 2009; 6: 138. PubMed Abstract | Publisher Full Text | Free Full Text

38. Skiadopoulos MH, Biacchesi S, Buchholz UJ, et al.: The two major human metapneumovirus genetic lineages are highly related antigenically, and the fusion $(F)$ protein is a major contributor to this antigenic relatedness. $J$ Virol. 2004; 78(13): 6927-37.

PubMed Abstract | Publisher Full Text | Free Full Text

39. Tang RS, Mahmood K, Macphail M, et al:: A host-range restricted parainfluenza virus type 3 (PIV3) expressing the human metapneumovirus (hMPV) fusion protein elicits protective immunity in African green monkeys. Vaccine. 2005; 23(14): 1657-67.

PubMed Abstract | Publisher Full Text

40. MacPhail M, Schickli JH, Tang RS, et al:: Identification of small-animal and primate models for evaluation of vaccine candidates for human metapneumovirus (hMPV) and implications for hMPV vaccine design. J Gen Virol. 2004; 85(Pt 6): 1655-63.

PubMed Abstract | Publisher Full Text

41. Williams JV, Edwards KM, Weinberg GA, et al:: Population-based incidence of human metapneumovirus infection among hospitalized children. $J$ Infect Dis. 2010; 201(12): 1890-8.

PubMed Abstract | Publisher Full Text | Free Full Text

42. Howard LM, Edwards KM, Zhu Y, et al:: Clinical Features of Human Metapneumovirus Infection in Ambulatory Children Aged 5-13 Years. J Pediatric Infect Dis Soc. 2017.

PubMed Abstract | Publisher Full Text 
43. Walsh EE, Peterson DR, Falsey AR: Human metapneumovirus infections in adults: another piece of the puzzle. Arch Intern Med. 2008; 168(22): 2489-96. PubMed Abstract | Publisher Full Text | Free Full Text

44. Edwards KM, Zhu Y, Griffin MR, et al:: Burden of human metapneumovirus infection in young children. N Engl J Med. 2013; 368(7): 633-43. PubMed Abstract | Publisher Full Text | Free Full Text

45. Williams JV, Wang CK, Yang CF, et al. The role of human metapneumovirus in upper respiratory tract infections in children: a 20 -year experience. $J$ Infect Dis. 2006; 193(3): 387-95.

PubMed Abstract | Publisher Full Text | Free Full Text

46. Ebihara $\mathrm{T}$, Endo $\mathrm{R}$, Kikuta $\mathrm{H}$, et al:: Seroprevalence of human metapneumovirus in Japan. J Med Virol. 2003; 70(2): 281-3. PubMed Abstract | Publisher Full Text

47. Wolf DG, Zakay-Rones Z, Fadeela A, et al:: High seroprevalence of human metapneumovirus among young children in Israel. J Infect Dis. 2003; 188(12): 1865-7.

PubMed Abstract | Publisher Full Text

48. Pavlin JA, Hickey AC, Ulbrandt N, et al.: Human metapneumovirus reinfection among children in Thailand determined by ELISA using purified soluble fusion protein. J Infect Dis. 2008; 198(6): 836-42.

PubMed Abstract | Publisher Full Text | Free Full Text

49. Lüsebrink J, Wiese C, Thiel A, et al.: High seroprevalence of neutralizing capacity against human metapneumovirus in all age groups studied in Bonn, Germany. Clin Vaccine Immunol. 2010; 17(3): 481-4. PubMed Abstract | Publisher Full Text | Free Full Text

50. Dunn SR, Ryder AB, Tollefson SJ, et al:: Seroepidemiologies of human metapneumovirus and respiratory syncytial virus in young children, determined with a new recombinant fusion protein enzyme-linked immunosorbent assay. Clin Vaccine Immunol. 2013; 20(10): 1654-6. PubMed Abstract | Publisher Full Text | Free Full Text

51. Bosis S, Esposito S, Niesters HG, et al.: Impact of human metapneumovirus in childhood: comparison with respiratory syncytial virus and influenza viruses. J Med Virol. 2005; 75(1): 101-4. PubMed Abstract | Publisher Full Text

52. Boivin G, De Serres G, Côté S, et al.: Human metapneumovirus infections in hospitalized children. Emerging Infect Dis. 2003; 9(6): 634-40. PubMed Abstract | Publisher Full Text | Free Full Text

53. Peiris JS, Tang WH, Chan $\mathrm{K}$, et al:: Children with respiratory disease associated with metapneumovirus in Hong Kong. Emerging Infect Dis. 2003; 9(6): 628-33. PubMed Abstract | Publisher Full Text | Free Full Text

54. van den Hoogen BG, van Doornum GJ, Fockens JC, et al: Prevalence and clinical symptoms of human metapneumovirus infection in hospitalized patients. $J$ Infect Dis. 2003; 188(10): 1571-7. PubMed Abstract | Publisher Full Text

55. McAdam AJ, Hasenbein ME, Feldman HA, et al:: Human metapneumovirus in children tested at a tertiary-care hospital. J Infect Dis. 2004; 190(1): 20-6. PubMed Abstract | Publisher Full Text

56. Anderson EJ, Simões EA, Buttery JP, et al:: Prevalence and Characteristics of Human Metapneumovirus Infection Among Hospitalized Children at High Risk for Severe Lower Respiratory Tract Infection. J Pediatric Infect Dis Soc. 2012; 1(3): 212-22.

PubMed Abstract | Publisher Full Text

57. Aberle $\mathrm{JH}$, Aberle SW, Redlberger-Fritz M, et al.: Human metapneumovirus subgroup changes and seasonality during epidemics. Pediatr Infect Dis J. 2010; 29(11): 1016-8.

PubMed Abstract

58. Wei HY, Tsao KC, Huang CG, et al:: Clinical features of different genotypes/ genogroups of human metapneumovirus in hospitalized children. J Microbiol Immunol Infect. 2013; 46(5): 352-7.

PubMed Abstract | Publisher Full Tex

59. Schuster JE, Khuri-Bulos N, Faouri S, et al:: Human Metapneumovirus Infection in Jordanian Children: Epidemiology and Risk Factors for Severe Disease. Pediatr Infect Dis J. 2015; 34(12): 1335-41. PubMed Abstract | Publisher Full Text | Free Full Text

60. van den Hoogen BG, Osterhaus DM, Fouchier RA, et al:: Clinical impact and diagnosis of human metapneumovirus infection. Pediatr Infect Dis $J .2004$ 23(1 Suppl): S25-32.

PubMed Abstract | Publisher Full Tex

61. Williams JV, Tollefson SJ, Heymann PW, et al:: Human metapneumovirus infection in children hospitalized for wheezing. J Allergy Clin Immunol. 2005; 115(6): 1311-2.

PubMed Abstract | Publisher Full Text | Free Full Text

62. F Jain S, Williams DJ, Arnold SR, et al:: Community-acquired pneumonia requiring hospitalization among U.S. children. N Engl J Med. 2015; 372(9): $835-45$.

PubMed Abstract | Publisher Full Text | Free Full Text | F1000 Recommendation

63. F Self WH, Williams DJ, Zhu Y, et al.: Respiratory Viral Detection in Children and Adults: Comparing Asymptomatic Controls and Patients With CommunityAcquired Pneumonia. J Infect Dis. 2016; 213(4): 584-91. PubMed Abstract | Publisher Full Text | Free Full Text | F1000 Recommendation

64. Chano $\mathrm{F}$, Rousseau $\mathrm{C}$, Laferrière $\mathrm{C}$, et al.: Epidemiological survey of human metapneumovirus infection in a large pediatric tertiary care center. J Clin
Microbiol. 2005; 43(11): 5520-5.

PubMed Abstract | Publisher Full Text | Free Full Text

65. Kim YK, Lee HJ: Human metapneumovirus-associated lower respiratory tract infections in korean infants and young children. Pediatr Infect Dis J. 2005;

24(12): 1111-2.

PubMed Abstrac

66. Klein Ml, Coviello S, Bauer G, et al:: The impact of infection with human metapneumovirus and other respiratory viruses in young infants and children at high risk for severe pulmonary disease. J Infect Dis. 2006; 193(11): 1544-51. PubMed Abstract | Publisher Full Text

67. Madhi SA, Ludewick $\mathrm{H}$, Abed $\mathrm{Y}$, et al:: Human metapneumovirusassociated lower respiratory tract infections among hospitalized human immunodeficiency virus type 1 (HIV-1)-infected and HIV-1-uninfected African infants. Clin Infect Dis. 2003; 37(12): 1705-10.

PubMed Abstract | Publisher Full Text

68. Boivin G, De Serres G, Hamelin ME, et al:: An outbreak of severe respiratory tract infection due to human metapneumovirus in a long-term care facility. Clin Infect Dis. 2007; 44(9): 1152-8.

PubMed Abstract | Publisher Full Tex

69. Williams JV, Crowe JE Jr, Enriquez R, et al.: Human metapneumovirus infection plays an etiologic role in acute asthma exacerbations requiring hospitalization in adults. $J$ Infect Dis. 2005; 192(7): 1149-53. PubMed Abstract | Publisher Full Text | Free Full Text

70. F García-García ML, Calvo C, Casas I, et al:: Human metapneumovirus bronchiolitis in infancy is an important risk factor for asthma at age 5. Pediatr Pulmonol. 2007; 42(5): 458-64.

PubMed Abstract | Publisher Full Text | F1000 Recommendation

71. F Scheuerman O, Barkai G, Mandelboim M, et al:: Human metapneumovirus (hMPV) infection in immunocompromised children. J Clin Virol. 2016; 83: 12-6. PubMed Abstract | Publisher Full Text | F1000 Recommendation

72. Spaeder MC, Custer JW, Bembea MM, et al:: A multicenter outcomes analysis of children with severe viral respiratory infection due to human metapneumovirus. Pediatr Crit Care Med. 2013; 14(3): 268-72.

PubMed Abstract | Publisher Full Text

73. Ampofo K, Bender J, Sheng $\mathrm{X}$, et al.: Seasonal invasive pneumococcal disease in children: role of preceding respiratory viral infection. Pediatrics. 2008; 122(2): 229-37.

PubMed Abstract | Publisher Full Text

74. Seki M, Yoshida H, Gotoh K, et al:: Severe respiratory failure due to co-infection with human metapneumovirus and Streptococcus pneumoniae. Respir Med Case Rep. 2014; 12: 13-5.

PubMed Abstract | Publisher Full Text | Free Full Text

75. Esper F, Martinello RA, Boucher D, et al:: A 1-year experience with human metapneumovirus in children aged $<5$ years. J Infect Dis. 2004; 189(8): 1388-96. PubMed Abstract | Publisher Full Text

76. Wyde PR, Chetty SN, Jewell AM, et al:: Development of a cotton rat-human metapneumovirus (hMPV) model for identifying and evaluating potential hMPV antivirals and vaccines. Antiviral Res. 2005; 66(1): 57-66.

PubMed Abstract | Publisher Full Text

77. Williams JV, Tollefson SJ, Johnson JE, et al.: The cotton rat (Sigmodon hispidus) is a permissive small animal model of human metapneumovirus infection, pathogenesis, and protective immunity. J Virol. 2005; 79(17): 10944-51. PubMed Abstract | Publisher Full Text | Free Full Text

78. Zhang Y, Niewiesk S, Li J, et al:: Small Animal Models for Human Metapneumovirus: Cotton Rat is More Permissive than Hamster and Mouse. Pathogens. 2014; 3(3): 633-55.

PubMed Abstract | Publisher Full Text | Free Full Text

79. Darniot M, Petrella T, Aho S, et al.: Immune response and alteration of pulmonary function after primary human metapneumovirus (hMPV) infection of BALB/c mice. Vaccine. 2005; 23(36): 4473-80. PubMed Abstract | Publisher Full Text

80. Kolli D, Bataki EL, Spetch L, et al.: T lymphocytes contribute to antiviral immunity and pathogenesis in experimental human metapneumovirus infection. J Virol. 2008; 82(17): 8560-9. PubMed Abstract | Publisher Full Text | Free Full Tex

81. Kukavica-Ibrulj I, Hamelin ME, Prince GA, et al.: Infection with human metapneumovirus predisposes mice to severe pneumococcal pneumonia. $J$ Virol. 2009; 83(3): 1341-9.

PubMed Abstract | Publisher Full Text | Free Full Text

82. Hamelin ME, Prince GA, Gomez AM, et al.: Human metapneumovirus infection induces long-term pulmonary inflammation associated with airway obstruction and hyperresponsiveness in mice. J Infect Dis. 2006; 193(12) 1634-42.

PubMed Abstract | Publisher Full Text

83. $\mathrm{F}$ Hamelin M, Yim K, Kuhn KH, et al:: Pathogenesis of human metapneumovirus lung infection in BALB/c mice and cotton rats. J Virol. 2005; 79(14): 8894-903. PubMed Abstract | Publisher Full Text | Free Full Text | F1000 Recommendation

84. Zhang J, Dou Y, Wu J, et al:: Effects of $\boldsymbol{N}$-linked glycosylation of the fusion protein on replication of human metapneumovirus in vitro and in mouse lungs. J Gen Virol. 2011; 92(Pt 7): 1666-75. PubMed Abstract | Publisher Full Tex

85. Huck B, Neumann-Haefelin D, Schmitt-Graeff A, et al.: Human metapneumovirus 
induces more severe disease and stronger innate immune response in BALB/C mice as compared with respiratory syncytial virus. Respir Res. 2007; 8: 6 . PubMed Abstract | Publisher Full Text | Free Full Text

86. Hastings AK, Erickson JJ, Schuster JE, et al:: Role of type I interferon signaling in human metapneumovirus pathogenesis and control of viral replication. $J$ Virol. 2015; 89(8): 4405-20

PubMed Abstract | Publisher Full Text | Free Full Text

87. Ren J, Kolli D, Deng J, et al:: MyD88 controls human metapneumovirus-induced pulmonary immune responses and disease pathogenesis. Virus Res. 2013; 176(1-2): 241-50.

PubMed Abstract | Publisher Full Text | Free Full Text

88. Wen SC, Tollefson SJ, Johnson M, et al: Acute clearance of human metapneumovirus occurs independently of natural killer cells. J Virol. 2014; 88(18): 10963-9.

PubMed Abstract | Publisher Full Text | Free Full Text

89. Erickson JJ, Gilchuk $\mathrm{P}$, Hastings AK, et al:: Viral acute lower respiratory infections impair CD8+ T cells through PD-1. J Clin Invest. 2012; 122(8): 2967-82. PubMed Abstract | Publisher Full Text | Free Full Text

90. Darniot M, Pitoiset C, Petrella T, et al:: Age-associated aggravation of clinical disease after primary metapneumovirus infection of BALB/c mice. $J$ Virol. 2009; 83(7): 3323-32.

PubMed Abstract | Publisher Full Text | Free Full Text

91. Cseke G, Wright DW, Tollefson SJ, et al:: Human metapneumovirus fusion protein vaccines that are immunogenic and protective in cotton rats. $J$ Virol. 2007; 81(2): 698-707.

PubMed Abstract | Publisher Full Text | Free Full Text

92. Skiadopoulos MH, Biacchesi S, Buchholz UJ, et al.: Individual contributions of the human metapneumovirus $\mathrm{F}, \mathrm{G}$, and $\mathrm{SH}$ surface glycoproteins to the induction of neutralizing antibodies and protective immunity. Virology. 2006; 345(2): 492-501.

PubMed Abstract | Publisher Full Text

93. Hamelin ME, Couture C, Sackett M, et al.: The prophylactic administration of monoclonal antibody against human metapneumovirus attenuates viral disease and airways hyperresponsiveness in mice. Antivir Ther. 2008; 13(1): $39-46$.

PubMed Abstract

94. Williams JV, Chen Z, Cseke G, et al:: A recombinant human monoclonal antibody to human metapneumovirus fusion protein that neutralizes virus in vitro and is effective therapeutically in vivo. $J$ Virol. 2007: 81(15): 8315-24. PubMed Abstract | Publisher Full Text | Free Full Text

95. Corti D, Bianchi S, Vanzetta $F$, et al.: Cross-neutralization of four paramyxoviruses by a human monoclonal antibody. Nature. 2013; 501(7467): 439-43. PubMed Abstract | Publisher Full Tex

96. Schuster JE, Cox RG, Hastings AK, et al:: A broadly neutralizing human monoclonal antibody exhibits in vivo efficacy against both human metapneumovirus and respiratory syncytial virus. J Infect Dis. 2015; 211(2): 216-25.

PubMed Abstract | Publisher Full Text | Free Full Text

97. van den Hoogen BG, Herfst S, de Graaf M, et al:: Experimental infection of macaques with human metapneumovirus induces transient protective immunity. J Gen Virol. 2007; 88(Pt 4): 1251-9.

PubMed Abstract | Publisher Full Tex

98. Falsey AR, Hennessey PA, Formica MA, et al.: Humoral immunity to human metapneumovirus infection in adults. Vaccine. 2010; 28(6): 1477-80. PubMed Abstract | Publisher Full Text | Free Full Text

99. Alvarez R, Harrod KS, Shieh W, et al:: Human metapneumovirus persists in BALB/c mice despite the presence of neutralizing antibodies. $J$ Virol. 2004; 78(24): 14003-11.

PubMed Abstract | Publisher Full Text | Free Full Text

100. Erickson JJ, Rogers MC, Hastings AK, et al.: Programmed death-1 impairs secondary effector lung $C D 8^{+} T$ cells during respiratory virus reinfection. J Immunol. 2014; 193(10): 5108-17.

PubMed Abstract | Publisher Full Text | Free Full Text

101. Wen SC, Schuster JE, Gilchuk P, et al.: Lung CD8+ T Cell Impairment Occurs during Human Metapneumovirus Infection despite Virus-Like Particle Induction of Functional CD8+ T Cells. J Virol. 2015; 89(17): 8713-26. PubMed Abstract | Publisher Full Text | Free Full Text

102. Dinwiddie DL, Harrod KS: Human metapneumovirus inhibits IFN-alpha signaling through inhibition of STAT1 phosphorylation. Am J Respir Cell Mol Biol. 2008; 38(6): 661-70.

PubMed Abstract | Publisher Full Text

103. Bao X, Kolli D, Liu T, et al:: Human metapneumovirus small hydrophobic protein inhibits NF-kappaB transcriptional activity. J Virol. 2008; 82(16): 8224-9. PubMed Abstract | Publisher Full Text | Free Full Text

104. Goutagny N, Jiang Z, Tian J, et al.: Cell type-specific recognition of human metapneumoviruses (HMPVs) by retinoic acid-inducible gene I (RIG-I) and TLR7 and viral interference of RIG-I ligand recognition by HMPV-B1 phosphoprotein. J Immunol. 2010; 184(3): 1168-79. PubMed Abstract | Publisher Full Text | Free Full Text

105. Bao X, Kolli D, Ren J, et al:: Human metapneumovirus glycoprotein G disrupts mitochondrial signaling in airway epithelial cells. PLoS One. 2013; 8(4): e62568. PubMed Abstract | Publisher Full Text | Free Full Text

106. Guerrero-Plata A, Casola A, Suarez G, et al.: Differential response of dendritic cells to human metapneumovirus and respiratory syncytial virus. Am J Respir Cell Mol Biol. 2006; 34(3): 320-9.

PubMed Abstract | Publisher Full Text | Free Full Text

107. Céspedes PF, Gonzalez PA, Kalergis AM: Human metapneumovirus keeps dendritic cells from priming antigen-specific naive T cells. Immunology. 2013; 139(3): 366-76

PubMed Abstract | Publisher Full Text | Free Full Text

108. Tan MC, Battini L, Tuyama AC, et al:: Characterization of human metapneumovirus infection of myeloid dendritic cells. Virology. 2007; 357(1): 1-9. PubMed Abstract | Publisher Full Text | Free Full Text

109. Guerrero-Plata A, Kolli D, Hong C, et al:: Subversion of pulmonary dendritic cell function by paramyxovirus infections. $J$ Immunol. 2009; 182(5): 3072-83. PubMed Abstract | Publisher Full Text | Free Full Text

110. Le Nouën C, Munir S, Losq S, et al.: Infection and maturation of monocytederived human dendritic cells by human respiratory syncytial virus, human metapneumovirus, and human parainfluenza virus type 3. Virology. 2009; 385(1): 169-82.

PubMed Abstract | Publisher Full Text | Free Full Text

111. Le Nouën $C$, Hillyer $P$, Munir $S$, et al:: Effects of human respiratory syncytial virus, metapneumovirus, parainfluenza virus 3 and influenza virus on CD4+ cell activation by dendritic cells. PLOS One. 2010; 5(11): e15017. PubMed Abstract | Publisher Full Text | Free Full Text

112. Le Nouën $C$, Hillyer $P$, Winter $C C$, et al.: Low CCR7-mediated migration of human monocyte derived dendritic cells in response to human respiratory syncytial virus and human metapneumovirus. PLoS Pathog. 2011; 7(6): e1002105. PubMed Abstract | Publisher Full Text | Free Full Text

113. F Barber DL, Wherry EJ, Masopust $\mathrm{D}$, et al.: Restoring function in exhausted CD8 T cells during chronic viral infection. Nature. 2006; 439(7077): 682-7. PubMed Abstract | Publisher Full Text | F1000 Recommendation

114. Côté S, Abed Y, Boivin G: Comparative evaluation of real-time PCR assays for detection of the human metapneumovirus. J Clin Microbiol. 2003; 41(8): 3631-5. PubMed Abstract | Publisher Full Text | Free Full Text

115. Maertzdorf J, Wang CK, Brown JB, et al.: Real-time reverse transcriptase PCR assay for detection of human metapneumoviruses from all known genetic lineages. J Clin Microbiol. 2004; 42(3): 981-6. PubMed Abstract | Publisher Full Text | Free Full Text

116. Klemenc J, Asad Ali S, Johnson M, et al:: Real-time reverse transcriptase PCR assay for improved detection of human metapneumovirus. J Clin Virol. 2012; 54(4): 371-5. PubMed Abstract | Publisher Full Text | Free Full Text

117. Popowitch EB, O'Neill SS, Miller MB: Comparison of the Biofire FilmArray RP, Genmark eSensor RVP, Luminex xTAG RVPv1, and Luminex xTAG RVP fas multiplex assays for detection of respiratory viruses. J Clin Microbiol. 2013; 51(5): 1528-33.

PubMed Abstract | Publisher Full Text | Free Full Text

118. Tollefson SJ, Cox RG, Williams JV: Studies of culture conditions and environmental stability of human metapneumovirus. Virus Res. 2010; 151(1): 54-9.

PubMed Abstract | Publisher Full Text | Free Full Text

119. Wyde PR, Chetty SN, Jewell AM, et al:: Comparison of the inhibition of human metapneumovirus and respiratory syncytial virus by ribavirin and immune serum globulin in vitro. Antiviral Res. 2003; 60(1): 51-9. PubMed Abstract | Publisher Full Text

120. Hamelin M, Prince GA, Boivin G: Effect of ribavirin and glucocorticoid treatment in a mouse model of human metapneumovirus infection. Antimicrob Agents Chemother. 2006; 50(2): 774-7.

PubMed Abstract | Publisher Full Text | Free Full Text

121. F Shah DP, Shah PK, Azzi JM, et al:: Human metapneumovirus infections in hematopoietic cell transplant recipients and hematologic malignancy patients: A systematic review. Cancer Lett. 2016; 379(1): 100-6.

PubMed Abstract | Publisher Full Text | Free Full Text | F1000 Recommendation

122. Herfst S, de Graaf M, Schrauwen EJ, et al.: Generation of temperature-sensitive human metapneumovirus strains that provide protective immunity in hamsters. J Gen Virol. 2008; 89(Pt 7): 1553-62.

PubMed Abstract | Publisher Full Text

123. Herfst S, Schrauwen EJ, de Graaf M, et al:: Immunogenicity and efficacy of two candidate human metapneumovirus vaccines in cynomolgus macaques. Vaccine. 2008; 26(33): 4224-30.

PubMed Abstract | Publisher Full Text

124. Buchholz UJ, Biacchesi S, Pham QN, et al.: Deletion of M2 gene open reading frames 1 and 2 of human metapneumovirus: effects on RNA synthesis attenuation, and immunogenicity. J Virol. 2005; 79(11): 6588-97. PubMed Abstract | Publisher Full Text | Free Full Text

125. F Tedcastle AB, Fenwick F, Robinson MJ, et al:: Immunogenicity in mice of human metapneumovirus with a truncated SH glycoprotein. $J$ Med Virol. 2014; 86(4): 547-57

PubMed Abstract | Publisher Full Text | F1000 Recommendation

126. $\mathrm{F}$ Zhang $\mathrm{Y}$, Wei $\mathrm{Y}$, Zhang $\mathrm{X}$, et al:: Rational design of human metapneumovirus live attenuated vaccine candidates by inhibiting viral mRNA cap methyltransferase. $J$ Virol. 2014; 88(19): 11411-29.

PubMed Abstract | Publisher Full Text | Free Full Text | F1000 Recommendation

127. $\mathrm{F}$ Wei $\mathrm{Y}$, Zhang $\mathrm{Y}$, Cai $\mathrm{H}$, et al:: Roles of the putative integrin-binding motif 
of the human metapneumovirus fusion (f) protein in cell-cell fusion, viral infectivity, and pathogenesis. J Virol. 2014; 88(8): 4338-52. PubMed Abstract | Publisher Full Text | Free Full Text | F1000 Recommendation

128. Pham QN, Biacchesi S, Skiadopoulos MH, et al:: Chimeric recombinant human metapneumoviruses with the nucleoprotein or phosphoprotein open reading frame replaced by that of avian metapneumovirus exhibit improved growth in vitro and attenuation in vivo. J Virol. 2005; 79(24): 15114-22. PubMed Abstract | Publisher Full Text | Free Full Text

129. Mok H, Tollefson SJ, Podsiad AB, et al:: An alphavirus replicon-based human metapneumovirus vaccine is immunogenic and protective in mice and cotton rats. J Virol. 2008; 82(22): 11410-8 PubMed Abstract | Publisher Full Text | Free Full Text

130. Bates JT, Pickens JA, Schuster JE, et al:: Immunogenicity and efficacy of alphavirus-derived replicon vaccines for respiratory syncytial virus and human metapneumovirus in nonhuman primates. Vaccine. 2016; 34(7): 950-6. PubMed Abstract | Publisher Full Text | Free Full Text

131. F Russell CJ, Jones BG, Sealy RE, et al.: A Sendai virus recombinant vaccine expressing a gene for truncated human metapneumovirus (hMPV) fusion protein protects cotton rats from hMPV challenge. Virology. 2017; 509: 60-6. PubMed Abstract | Publisher Full Text | Free Full Text | F1000 Recommendation

132. Talaat KR, Karron RA, Thumar B, et al.: Experimental infection of adults with recombinant wild-type human metapneumovirus. J Infect Dis. 2013; 208(10) 1669-78.

PubMed Abstract | Publisher Full Text | Free Full Text

133. F Karron RA, San Mateo J, Wanionek K, et al.: Evaluation of a Live Attenuated Human Metapneumovirus Vaccine in Adults and Children. $J$ Pediatric Infect Dis Soc. 2017. PubMed Abstract | Publisher Full Text | F1000 Recommendation

134. Fulginiti VA, Eller JJ, Sieber OF, et al.: Respiratory virus immunization. I. A field trial of two inactivated respiratory virus vaccines; an aqueous trivalent parainfluenza virus vaccine and an alum-precipitated respiratory syncytial virus vaccine. Am J Epidemiol. 1969; 89(4): 435-48. PubMed Abstract | Publisher Full Text

135. Kapikian AZ, Mitchell RH, Chanock RM, et al:: An epidemiologic study of altered clinical reactivity to respiratory syncytial (RS) virus infection in children previously vaccinated with an inactivated RS virus vaccine. Am J Epidemiol. 1969; 89(4): 405-21.

PubMed Abstract | Publisher Full Text

136. Kim HW, Canchola JG, Brandt CD, et al.: Respiratory syncytial virus disease in infants despite prior administration of antigenic inactivated vaccine. $A m \mathrm{~J}$ Epidemiol. 1969; 89(4): 422-34.

PubMed Abstract | Publisher Full Text

137. Prince GA, Jenson AB, Hemming VG, et al.: Enhancement of respiratory syncytial virus pulmonary pathology in cotton rats by prior intramuscular inoculation of formalin-inactiva ted virus. J Virol. 1986; 57(3): 721-8. PubMed Abstract | Free Full Text

138. Murphy BR, Sotnikov AV, Lawrence LA, et al.: Enhanced pulmonary histopathology is observed in cotton rats immunized with formalin-inactivated respiratory syncytial virus (RSV) or purified $\mathrm{F}$ glycoprotein and challenged with RSV 3-6 months after immunization. Vaccine. 1990; 8(5): 497-502. PubMed Abstract | Publisher Full Text

139. Hamelin M, Couture C, Sackett MK, et al.: Enhanced lung disease and Th2 response following human metapneumovirus infection in mice immunized with the inactivated virus. J Gen Virol. 2007; 88(Pt 12): 3391-400. PubMed Abstract | Publisher Full Text

140. Yim KC, Cragin RP, Boukhvalova MS, et al:: Human metapneumovirus: enhanced pulmonary disease in cotton rats immunized with formalininactivated virus vaccine and challenged. Vaccine. 2007; 25(27): 5034-40. PubMed Abstract | Publisher Full Text | Free Full Text

141. de Swart RL, van den Hoogen BG, Kuiken T, et al:: Immunization of macaques with formalin-inactivated human metapneumovirus induces hypersensitivity to hMPV infection. Vaccine. 2007; 25(51): 8518-28.

PubMed Abstract | Publisher Full Text

142. Cox RG, Erickson JJ, Hastings AK, et al.: Human metapneumovirus virus-like particles induce protective $B$ and T cell responses in a mouse model. $J$ Virol. 2014; 88(11): 6368-79. PubMed Abstract | Publisher Full Text | Free Full Text

143. Lévy C, Aerts L, Hamelin MĖ, et al:: Virus-like particle vaccine induces crossprotection against human metapneumovirus infections in mice. Vaccine. 2013; 31(25): 2778-85.

PubMed Abstract | Publisher Full Text

144. Herd KA, Mahalingam S, Mackay IM, et al:: Cytotoxic T-lymphocyte epitope vaccination protects against human metapneumovirus infection and disease in mice. J Virol. 2006; 80(4): 2034-44. PubMed Abstract | Publisher Full Text | Free Full Text

145. Li X, Guo L, Kong M, et al.: Design and Evaluation of a Multi-Epitope Peptide of Human Metapneumovirus. Intervirology. 2015; 58(6): 403-12.

PubMed Abstract | Publisher Full Text 


\section{Open Peer Review}

\section{Current Peer Review Status:}

\section{Editorial Note on the Review Process}

Faculty Reviews are review articles written by the prestigious Members of Faculty Opinions. The articles are commissioned and peer reviewed before publication to ensure that the final, published version is comprehensive and accessible. The reviewers who approved the final version are listed with their names and affiliations.

\section{The reviewers who approved this article are:}

\section{Version 1}

\section{Jianrong Li}

Department of Veterinary Biosciences, College of Veterinary Medicine, The Ohio State University, , Ohio, USA

Competing Interests: No competing interests were disclosed.

\section{Xiaoyong Bao}

Department of Pediatrics, University of Texas Medical Branch, Galveston, USA

Competing Interests: No competing interests were disclosed.

The benefits of publishing with F1000Research:

- Your article is published within days, with no editorial bias

- You can publish traditional articles, null/negative results, case reports, data notes and more

- The peer review process is transparent and collaborative

- Your article is indexed in PubMed after passing peer review

- Dedicated customer support at every stage

For pre-submission enquiries, contact research@f1000.com 